\title{
Cardiac Remodeling Following Percutaneous Mitral Valve Repair - Initial Results Assessed by Cardiovascular Magnetic Resonance Imaging
}

\section{Kardiales Remodeling nach perkutaner Mitralklappenrekonstruktion - erste Ergebnisse in der Beurteilung durch die kardiale Magnetresonanztomografie}

Authors

Affiliations
U. K. Radunski' ${ }^{1}$, O. Franzen ${ }^{2}$, A. Barmeyer ${ }^{3}$, M. Lange ${ }^{1}$, G. Lund ${ }^{4}$, V. Rudolph ${ }^{1}$, M. Schlüter ${ }^{1}$, G. Adam ${ }^{4}$, H. Reichenspurner ${ }^{5}$, S. Blankenberg ${ }^{1}$, S. Baldus ${ }^{1}$, K. Muellerleile $^{1}$

Affiliation addresses are listed at the end of the article.

Key words
heart
interventional procedures
MR imaging
artifacts
safety
echocardiography

received 21.6.2013 accepted 2.2.2014

\section{Bibliography}

DOI http://dx.doi.org/ 10.1055/s-0034-1366216

Published online: 19.3.2014 Fortschr Röntgenstr 2014; 186 : 951-958 @ Georg Thieme Verlag KG Stuttgart · New York ISSN 1438-9029

\section{Correspondence}

Herr Dr. Ulf Konrad Radunski Klinik für Allgemeine und Interventionelle Kardiologie, Universitäres Herzzentrum Hamburg

Martinistr. 52

20246 Hamburg

Germany

Tel.: ++ 49/74 10/53471

Fax: ++49/74 10/54591

u.radunski@uke.uni-

hamburg.de

\section{Zusammenfassung \\ $\nabla$}

Ziel: Die perkutane Mitralklappenrekonstruktion mittels MitraClip (Abbott Vascular, Redwood City, Kalifornien, USA) stellt ein neues therapeutisches Verfahren dar bei Patienten mit Mitralklappeninsuffizienz. In dieser Studie wurde die Machbarkeit der Volumetrie mittels kardialer Magnetresonanztomografie (MRT) zur Beurteilung eines kardialen Remodelings bei Patienten nach MitraClip-Implantation untersucht.

Material und Methoden: Zwölf Patienten wurden vor sowie sechs Monate nach MitraClip-Implantation mittels kardialer MRT untersucht. Zur Beurteilung von linksventrikulärem (LV), rechtsventrikulärem (RV) und linksatrialem (LA) Volumen wurden Cine-MRT-Sequenzen in Kurzachsenschichten und Langachsenschichten durchgeführt. Ergebnisse: Durch die perkutane Mitralklappenrekonstruktion bedingte Artefakte schränkten die Abgrenzbarkeit der endokardialen Konturen nicht ein. Es zeigten sich keine signifikanten Unterschiede in den Untersucherabweichungen der Messungen von LV-, RV- und LA-Volumen vor und nach MitraClip-Implantation. Hinsichtlich der Indices von enddiastolischem LV-Volumen (Median 127 [IQR $96-150$ ] vs. 112 [IQR $86-150] \mathrm{ml} / \mathrm{m}^{2}$; $\mathrm{p}=0,03$ ) und endsystolischem LV Volumen (Median 82 [IQR 54-91] vs. 69 [IQR $48-99$ ] $\mathrm{ml} / \mathrm{m}^{2}$; $\mathrm{p}=0,03$ ) zeigte sich jeweils eine signifikante Reduktion nach 6 Monaten im Vergleich zur Erstuntersuchung. Es konnten keine signifikanten Veränderungen der Indices von enddiastolischem RVVolumen (94 [75-103] vs. 99 [77-123] $\mathrm{ml} / \mathrm{m}^{2}$, $\mathrm{p}=0,91$ ), endsystolischem RV-Volumen (48 [42$80]$ vs. $\left.51[40-81] \mathrm{ml} / \mathrm{m}^{2} \mathrm{p}=0,48\right)$ und LA-Volumen $\left(87[55-124]\right.$ vs. $92[48-137] \mathrm{ml} / \mathrm{m}^{2}$, $\mathrm{p}=0,20) 6$ Monate nach MitraClip-Implantation nachgewiesen werden.

Schlussfolgerung: Die kardiale Magnetresonanztomografie erlaubt die Beurteilung kardialer Volumina bei Patienten nach MitraClip-Implanta-

\section{Abstract \\ $\nabla$}

Purpose: Percutaneous mitral valve repair with the MitraClip device (Abbott Vascular, Redwood City, California, USA) is a novel therapeutic option in patients with mitral regurgitation. This study evaluated the feasibility of cardiac volume measurements by cardiovascular magnetic resonance imaging (CMR) to assess reverse myocardial remodeling in patients after MitraClip implantation. Materials and Methods: 12 patients underwent CMR at baseline (BL) before and at 6 months follow-up (FU) after MitraClip implantation. CineCMR was performed in short- and long-axes for the assessment of left ventricular (LV), right ventricular (RV) and left atrial (LA) volumes.

Results: Assessment of endocardial contours was not compromised by the device-related artifact. No significant differences in observer variances were observed for LV, RV and LA volume measurements between BL and FU. LV end-diastolic (median 127 [IQR 96 - 150] vs. 112 [86-150] ml/m²; $\mathrm{p}=0.03$ ) and LV end-systolic (82 [54-91] vs. 69 [48-99] $\mathrm{ml} / \mathrm{m}^{2} ; \mathrm{p}=0.03$ ) volume indices decreased significantly from BL to FU. No significant differences were found for RV end-diastolic (94 [75-103] vs. 99 [77-123] $\left.\mathrm{ml} / \mathrm{m}^{2} ; \mathrm{p}=0.91\right), \mathrm{RV}$ end-systolic (48 [42-80] vs. $51[40-81] \mathrm{ml} / \mathrm{m}^{2}$; $\mathrm{p}=0.48)$, and LA $(87$ [55-124] vs. 92 [48 - 137] $\mathrm{ml} / \mathrm{m}^{2} ; \mathrm{p}=0.20$ ) volume indices between $\mathrm{BL}$ and FU.

Conclusion: CMR enables the assessment of cardiac volumes in patients after MitraClip implantation. Our CMR findings indicate that percutaneous mitral valve repair results in reverse LV but not in RV or LA remodeling.

Key points:

- Volume measurements by cardiovascular magnetic resonance imaging are feasible following percutaneous mitral valve repair despite device-related artifacts. 
tion. Unsere Ergebnisse deuten darüber hinaus auf ein reverses linksventrikuläres, nicht aber rechtsventrikuläres oder linksatriales Remodeling nach perkutaner Mitralklappenrekonstruktion hin.

Kernaussagen:

- Die kardiale Volumetrie mittels kardialer Magnetresonanztomografie ist nach MitraClip-Implantation trotz Artefakten machbar.

- Es ließ sich eine signifikante Reduktion der linksventrikulären Volumina 6 Monate nach perkutaner Mitralklappenrekonstruktion im Sinne eines günstigen, reversen Remodelings nachweisen.

- Signifikante Veränderungen der rechtsventrikulären oder linksatrialen Volumina ließen sich 6 Monate nach perkutaner Mitralklappenrekonstruktion nicht nachweisen.

\section{Introduction}

Severe mitral regurgitation (MR) is associated with a poor prognosis, particularly in patients with heart failure [1]. Surgical mitral valve reconstruction is the treatment of choice for symptomatic patients with severe MR [2]. The MitraClip (MC, Abbott Vascular, Redwood City, California, USA) is a novel device for percutaneous mitral valve repair that emulates the surgical edge-to-edge repair technique [3] ( $\bullet$ Fig. 1). The device has been compared to conventional surgical approaches in selected patients suitable for surgery. First, the EVEREST I trial demonstrated feasibility, safety and efficacy with a significant reduction in MR [4]. The EVEREST II trial compared MC therapy and mitral surgery (repair or replacement) and showed superior safety and a similar clinical outcome for patients with MC therapy despite a significantly inferior reduction of MR [5]. Furthermore, echocardiography demonstrated reverse left ventricular (LV) remodeling in terms of decreased LV volumes at one-year follow-up in patients not suitable for surgery [6].

Cardiovascular magnetic resonance imaging (CMR) is currently the reference method for the assessment of cardiac volumes and function [7, 8]. However, to date CMR has not been used to assess reverse remodeling after $\mathrm{MC}$ implantation. The $\mathrm{MC}$ system is CMR-capable and safe in humans up to field strengths of 3 Tesla (evaluated by Shellock R \& D Services, Inc., Los Angeles, USA, http://www.mrisafety.com/) but artifacts could potentially affect delineation of endocardial contours on CMR images. Thus, this study evaluated the ability of CMR to assess reverse ventricular and atrial remodeling in patients after MC implantation.

\section{Methods \\ $\nabla$}

\section{Patients}

CMR was performed in 12 consecutive patients with moderate to severe mitral regurgitation at baseline (BL) before and at a median [IQR] follow-up (FU) of 6 months after percutaneous mitral valve repair. The pathogenesis of mitral regurgitation was functional in 7 and degenerative in 5 patients. Surgical mitral valve repair was deemed contraindicated due to increased peri-operative risk assessed by a cardiovascular board consisting of cardiologists and cardiac surgeons experienced in the management of structural heart disease ("heart team approach") in all patients. Baseline patient characteristics are given in $\bullet$ Table 1. The study
- A significant reduction of left ventricular volume was found in terms of beneficial, reverse left ventricular remodeling after 6-month follow-up.

- No significant reduction was found in right ventricular or left atrial volumes after percutaneous mitral valve repair after 6-month follow-up.

\section{Citation Format:}

- Radunski UK, Franzen O, Barmeyer A et al. Cardiac Remodeling Following Percutaneous Mitral Valve Repair - Initial Results Assessed by Cardiovascular Magnetic Resonance Imaging. Fortschr Röntgenstr 2014; 186: 951-958

was approved by the local ethics committee and all patients gave their written informed consent.

\section{Echocardiography}

MR at baseline was graded by transthoracic echocardiography (Philips iE33, S5 - 1 sector probe ( 1 - $5 \mathrm{MHz}$ ), Philips Medical Systems, Best, The Netherlands). All studies were performed by an experienced investigator (V.R.) according to American Society of Echocardiography guidelines [9]. At follow-up, MR severity was assessed with the technique reported by Foster et al. as appropriate [10].

\section{CMR protocol}

CMR was performed using a 1.5 Tesla system (Achieva, Philips Medical Systems, Best, The Netherlands). All sequences were ECG-triggered and breath-held. Scout images were performed in axial, coronal and sagittal orientation. A retrospective vectorECG-gated cine-CMR stack was acquired in the short-axis orientation using a steady-state free precession (SSFP) sequence ( $\bullet$ Fig. 2), covering the entire LV and RV with contiguous slices for the assessment of LV and RV end-diastolic volumes (LVEDV/ RVEDV) as well as LV and RV end-systolic volumes (LVESV/ RVESV) to calculate LV/RV stroke volumes (LVSV/RVSV) and LV/ RV ejection fractions (LVEF/RVEF). Furthermore, cine-CMR was performed in the four-, three- and two-chamber orientations to assess LA volumes ( $\bullet$ Fig. 3). Typical imaging parameters of cineCMR were as follows: voxel size $1.56 \times 1.56 \times 8 \mathrm{~mm}^{3}, 2 \mathrm{~mm}$ gap, echo time $=1.7 \mathrm{~ms}$, repetition time $=3.3 \mathrm{~ms}$, flip angle $=60^{\circ}$, parallel imaging $=$ SENSE, effective temporal resolution $26 \mathrm{~ms}$ as recommended [11]. Retrospective gating was performed in all patients.

\section{Volumetric analysis}

Endocardial and epicardial borders were manually traced on enddiastolic and end-systolic images using the semi-automatic Segment Software, version 1.8 (Medviso, Lund, Sweden) [12]. The papillary muscles were excluded from the analysis ( $\bullet$ Fig. 2). "Adequate" diagnostic image quality was defined as an image quality enabling complete delineation of ventricular and atrial endocardial boundaries. Maximum, mid-diastolic and minimum LA volumes (LAV) were calculated using the biplane area-length method [13]. All derived volumes were indexed to the patients' body surface area using a standard formula [14], resulting in volume indices (LVEDVi, LVESVi, RVEDVi, RVESVi, LAVi) and stroke volume indices (LVSVi, RVSVi). 


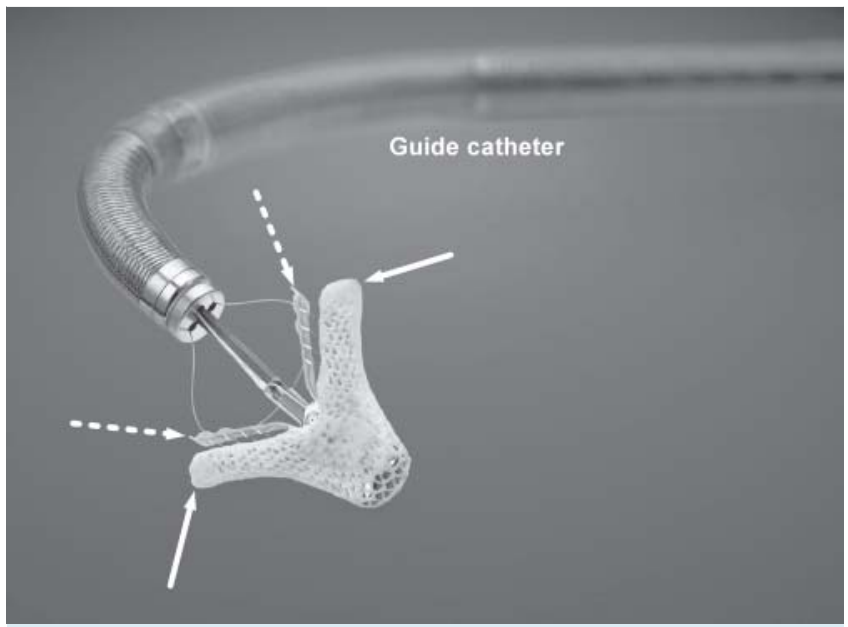

Fig. 1 MitraClip device. The MitraClip device is positioned and deployed using a steerable guide catheter and delivery system transvenously after puncture of the interatrial septum under transesophageal echocardiography guidance. The MitraClip device principally consists of "arms" (white arrows) and "grippers" (dotted arrows) for grasping the mitral valve leaflets, emulating the surgical "edge-to-edge" mitral valve repair. Courtesy of Abbott Vascular Structural Heart Germany (modified).

Abb. 1 MitraClip. Der MitraClip wird transvenös nach Punktion des atrialen Septums mittels steuerbarem Führungskatheter und Platzierungssystem und unter transösophagealer echokardiografischer Kontrolle positioniert und freigesetzt. Der MitraClip besteht aus „Armen“ und (weiße Pfeile) "Greifern“ (gepunktete Pfeile) zum Greifen der Mitralklappensegel in Anlehnung an die chirurgische „edge-to-egde“-Zusammennaht der Mitralklappensegel. Zur Verfügung gestellt von Abbot Vascular Structural Heart Germany (modifiziert).

Table 1 Baseline patient characteristics.

Tab. 1 Patienten (vor MitraClip-Implantation).

\begin{tabular}{ll}
\hline male gender & $(67 \%)$ \\
\hline logistic EuroSCORE (\%) & $20.3(3-40)$ \\
\hline STS mortality risk (\%) & $11.6(0.7-20.7)$ \\
\hline hypertension & $9(75 \%)$ \\
\hline hypercholesterolemia & $6(50 \%)$ \\
\hline diabetes & $4(25 \%)$ \\
\hline coronary artery disease & $8(67 \%)$ \\
\hline chronic obstructive pulmonary disease & $2(17 \%)$ \\
\hline atrial fibrillation & $6(50 \%)$ \\
\hline functional etiology & $7(58 \%)$ \\
\hline degenerative etiology & $5(42 \%)$ \\
\hline
\end{tabular}

Abbreviations: $C A D=$ Coronary Artery Disease, EuroSCORE $=$ European System for Cardiac Operative Risk Evaluation, STS = The Society of Thoracic Surgeons. Numbers are n (\% of total number).

Abkürzungen: $C A D=$ Coronary Artery Disease, EuroSCORE = European System for Cardiac Operative Risk Evaluation, STS = The Society of Thoracic Surgeons. Zahlen = Anzahl (\% der Gesamtzahl).

\section{Intra- and interobserver variability}

Two observers (UKR, ML) performed all CMR measurements. The first observer repeated measurements after an interval of at least one week to assess intraobserver agreement. Additional measurements were performed by a second observer to assess interobserver agreement. Both observers were blinded to the results of the first reading.

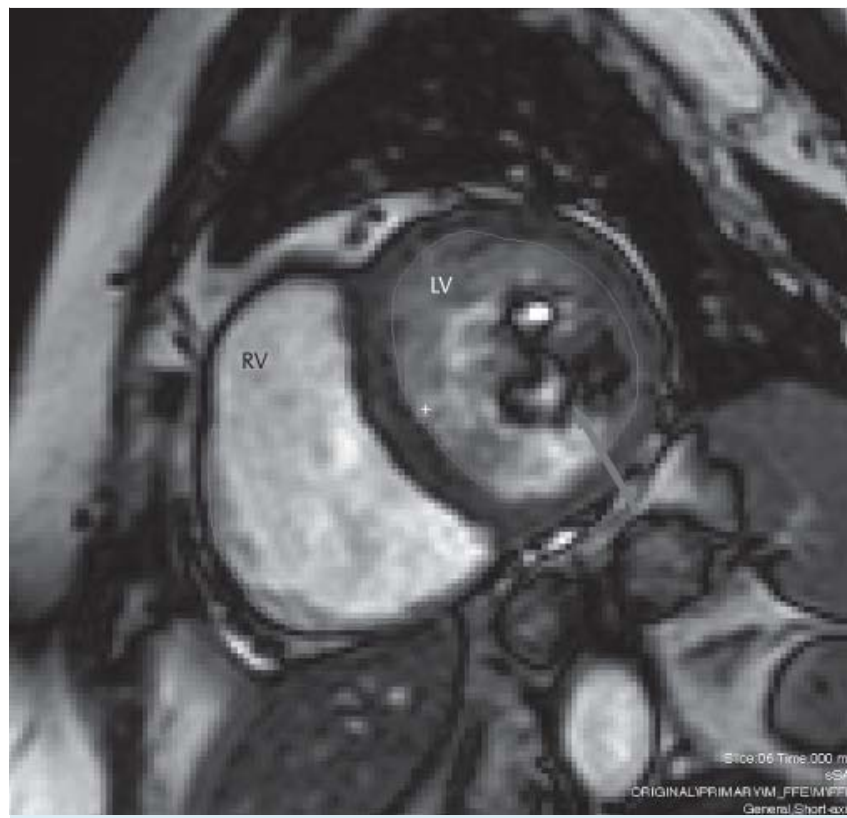

Fig. 2 CMR volume measurements. Short-axis cine-CMR view with RV (purple) and LV (red) contours as well as the MitraClip device-related artifact (green arrow). Abbreviations: $L V=$ left ventricular, RV = right ventricular.

Abb. 2 Volumetrie mittels kardialer MRT. Cine-MRT-Kurzachsenansicht der RV (violett) und LV (rot) Konturen und des MitraClip-bedingten Artefakts (grüner Pfeil). Abkürzungen: LV = linksventrikulär, RV= rechtsventrikulär.

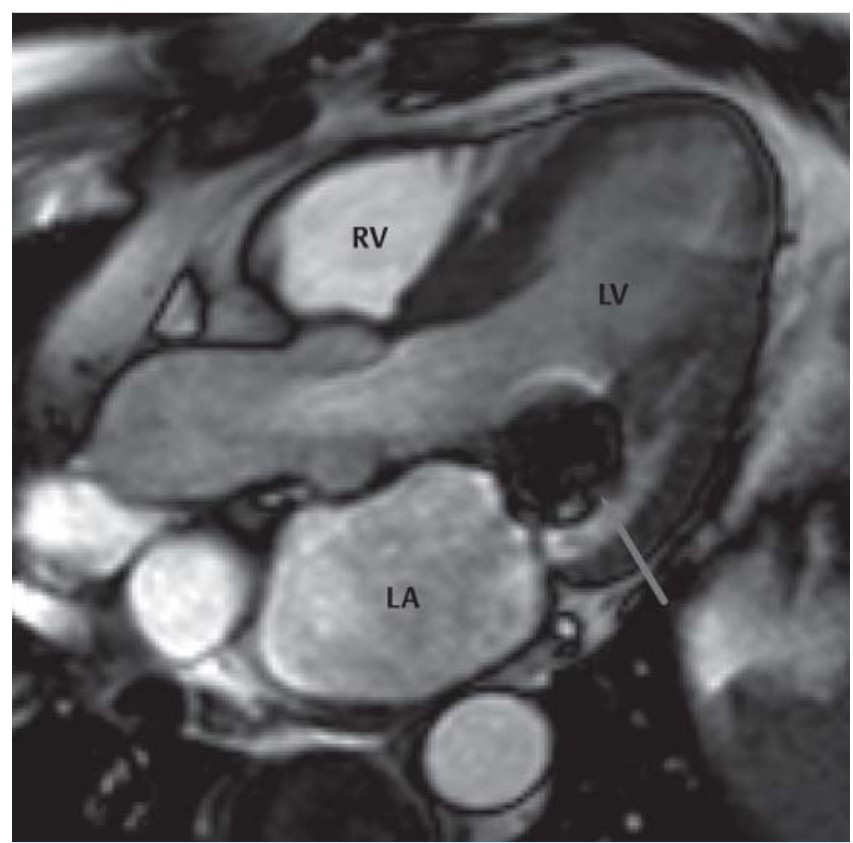

Fig. 3 MitraClip-related CMR artifact. MitraClip device-related artifact in 3-chamber cine-CMR view (green arrow). Abbreviations: $L A=l$ eft atrium, $\mathrm{LV}=$ left ventricle, $\mathrm{RV}=$ right ventricle.

Abb. 3 MitraClip-bedingtes Artefakt. MitraClip-bedingtes Artefakt im Cine-MRT-Dreikammerblick (grüner Pfeil). Abkürzungen: LA = linkes Atrium, LV = linker Ventrikel, RV = rechter Ventrikel. 


\section{Statistical analysis}

Statistical analysis was performed using GraphPad Prism version 5.00 for Windows (GraphPad Software, San Diego, California, USA). Normality testing was performed using the D'AgostinoPearson omnibus method. Continuous data are presented as median and interquartile range (IQR) and were compared by Wilcoxon's signed rank test. Categorical variables are presented as counts and percentages and were compared by McNemar's test with the continuity correction. Bland-Altman analysis was used to assess agreement between observers. Intra- and inter-observer variances were compared between $\mathrm{BL}$ and $\mathrm{FU}$ using the F-test. Statistical significance was assumed at $\mathrm{p}<0.05$.

\section{Results \\ $\nabla$}

\section{Procedural and clinical outcomes}

No severe periprocedural complications were observed. Initial device success was achieved in all patients with reduction of MR to grade $2+$ in 9 patients and grade $1+$ in 3 patients as assessed by echocardiography. In 10 patients $1 \mathrm{MC}$ was implanted and in 2 patients 2 clips were implanted. An improvement in exertional dyspnea at 6 months by at least 1 NYHA functional class was achieved in 10 patients (83\%), and in 2 patients (17\%) no improvement in NYHA class was observed. During the follow-up period 3 patients were rehospitalized due to non-cardiac events. Detailed patient characteristics at BL and FU are presented in - Table 2.

\section{Echocardiography}

Compared with baseline measurements, echocardiographic follow-up showed a non-significant reduction of LVEDVi (98 (77 $135)$ vs. $\left.91(74-118) \mathrm{ml} / \mathrm{m}^{2} ; \mathrm{p}=0.5382\right)$, LVESVi $(51(33-63)$ vs.

Table 2 Changes in echocardiographic and functional variables from $\mathrm{BL}$ to FU.

Tab. 2 Veränderungen echokardiografischer Parameter sowie funktioneller Variablen vor und 6 Monate nach MitraClip-Implantation.

\begin{tabular}{|c|c|c|c|}
\hline Variable & Baseline & Follow-up & p-value \\
\hline \multicolumn{4}{|l|}{ MR severity } \\
\hline $1+($ mild $)$ & $0(0)$ & $3(25)$ & 0.21 \\
\hline $2+($ mild to moderate $)$ & $0(0)$ & $9(75)$ & $<0.001$ \\
\hline $3+$ (moderate to severe) & $8(67)$ & $0(0)$ & 0.001 \\
\hline $4+($ severe $)$ & $4(33)$ & $0(0)$ & 0.09 \\
\hline \multicolumn{4}{|l|}{ NYHA functional class } \\
\hline I & 0 & $1(8)$ & 1.00 \\
\hline II & $1(8)$ & $9(75)$ & 0.01 \\
\hline III & $11(92)$ & $2(17)$ & $<0.01$ \\
\hline \multicolumn{4}{|l|}{$\begin{array}{l}\text { echocardiography } \\
\text { parameters }\end{array}$} \\
\hline $\begin{array}{l}\text { LV end-diastolic volume } \\
\text { index }\left(\mathrm{ml} / \mathrm{m}^{2}\right)\end{array}$ & $98(77-135)$ & $91(74-118)$ & 0.54 \\
\hline $\begin{array}{l}\text { LV end-systolic volume } \\
\text { index }\left(\mathrm{ml} / \mathrm{m}^{2}\right)\end{array}$ & $51(33-63)$ & $48(34-60)$ & 1.00 \\
\hline $\begin{array}{l}\text { LV stroke volume index } \\
\left(\mathrm{ml} / \mathrm{m}^{2}\right)\end{array}$ & $50(47-63)$ & $41(36-51)$ & 0.06 \\
\hline LV ejection fraction (\%) & $53(48-57)$ & $53(42-56)$ & 0.67 \\
\hline
\end{tabular}

Abbreviations: $L V=$ left ventricular, $L V E F=$ left ventricular ejection fraction, $M R=$ mitral regurgitation, NYHA = New York Heart Association. Numbers are $n$ (\% of total column number) for categorical and median (interquartile range) for continuous data.

Abkürzungen: $L V=$ linksventrikulär, $L V E F=$ linksventrikuläre Ejektionsfraktion, $M R=$ Mitralklappeninsuffizienz, NYHA = New York Heart Association. Zahlen = Anzahl (\% der Gesamtzahl) für kategorische Daten, Median (Interquartilsabstand) für kontinuierliche Daten. $\left.48(34-60) \mathrm{ml} / \mathrm{m}^{2} ; \mathrm{p}=1000\right), \operatorname{LVSVi}(50(47-63)$ vs. $41(36-51)$ $\left.\mathrm{ml} / \mathrm{m}^{2} ; \mathrm{p}=0.0648\right)$ and no difference in $\operatorname{LVEF}(53(48-57)$ vs. 53 $(42-56) \% ; p=0.6659)$.

\section{CMR}

CMR scanning was well tolerated by all patients at both BL and FU. There were no complications related to CMR. Echocardiography demonstrated no changes in MC device function and localization in any patient after the performance of CMR. All images were of adequate quality to enable measurement of $\mathrm{LV}, \mathrm{RV}$ and LA volumes.

\section{Intra- and interobserver variability}

Intra- and interobserver biases are given in 0 Table 3. No significant differences between BL and FU in intra- or interobserver variances were found. Intraobserver biases were small, ranging from $0.1 \%$ to $1.7 \%$ both at BL and FU. Interobserver biases were greater, varying between $0.6 \%$ and $13.7 \%$. Variability was generally larger for LA than for ventricular measurements.

\section{Reverse LV remodeling}

- Table 4 demonstrates LV variables at BL and FU by CMR. The median LVEDVi and LVESVi decreased significantly by $12 \%$ and $16 \%$, respectively ( Fig.4). All patients showed a reduction in LVESVi and 11 of 12 (92\%) patients showed a reduction in LVEDVi from BL to FU. No significant differences were found for LVSVi and LVEF.

\section{RV and LA volumes}

$\mathrm{RV}$ and LA variables by CMR are shown in $\odot$ Table 4. No significant differences were found for RVEDVi ( $\bullet$ Fig.5), RVESVi, RVSVi, RVEF and LA volume ( $\bullet$ Fig. $\mathbf{6}$ ) between BL and FU.

\section{Discussion}

To the best of our knowledge, this is the first study evaluating the use of CMR for assessing reverse remodeling in patients undergoing MC implantation. Our major findings were: First, CMR measurements of LV, RV and LA volumes are feasible in patients with implanted MC devices. Second, our CMR findings on reverse LV remodeling after MC implantation are consistent with recent data by echocardiography $[5,6]$. Third, we did not observe significant changes in RV or LA volumes after MC implantation.

\section{Intra- and interobserver variability}

There is only one case report of Altiok et al. on the performance of CMR in a patient with an implanted MC device [15]. In agreement with this case report, we observed local device-related artifacts at the tips of the mitral valve leaflets in all patients. These artifacts did not affect delineation of endocardial LV or LA contours ( $\bullet$ Fig. 2, 3). However, we cannot exclude minor imprecisions at the border of the papillary muscles related to these artifacts ( $\odot$ Fig. 2). According to guideline recommendations [11], an SSFP sequence was used for cine CMR. However, the use of Spoiled Gradient Echo (Fast Low Angle SHot $=$ FLASH) could have resulted in a further reduction of artifact size. The variability of $\mathrm{LV}, \mathrm{RV}$ and $\mathrm{LA}$ volumetric analyses was similar to reference values in the literature [16 - 19]. Regarding ventricular parameters, the highest interobserver variability was found for RVESV, in accordance with previous reports [18-21]. This may be related to diffi- 


\begin{tabular}{lccccc} 
& BASELINE & & FOLLOW-UP & & p-value \\
\cline { 2 - 6 } & Bias \pm SD $(\%)$ & Variance $\left(\mathbf{\%}^{2}\right)$ & Bias \pm SD $(\%)$ & Variance $\left({ }^{2}\right)$ & \\
\hline LVEDV-INTRA & $0.6 \pm 2.3$ & 5.3 & $0.9 \pm 2.0$ & 4.0 & 0.32 \\
\hline LVEDV-INTER & $1.5 \pm 2.2$ & 4.8 & $1.6 \pm 2.9$ & 8.4 & 0.18 \\
\hline LVESV-INTRA & $0.8 \pm 3.1$ & 9.6 & $0.3 \pm 4.7$ & 22.1 & 0.09 \\
\hline LVESV-INTER & $0.6 \pm 4.7$ & 22.1 & $1.8 \pm 6.4$ & 41.0 & 0.16 \\
\hline RVEDV-INTRA & $0.6 \pm 2.7$ & 7.3 & $0.1 \pm 2.9$ & 8.4 & 0.41 \\
\hline RVEDV-INTER & $1.0 \pm 5.7$ & 32.5 & $2.2 \pm 3.7$ & 13.7 & 0.08 \\
\hline RVESV-INTRA & $1.6 \pm 7.6$ & 57.8 & $1.7 \pm 7.8$ & 60.8 & 0.47 \\
\hline RVESV-INTER & $2.5 \pm 8.7$ & 75.7 & $3.5 \pm 8.8$ & 77.4 & 0.32 \\
\hline LAV-INTRA & $0.9 \pm 4.8$ & 23.0 & $0.3 \pm 7.6$ & 57.8 & 0.07 \\
\hline LAV-INTER & $10.7 \pm 9.7$ & 94.0 & $13.7 \pm 14.0$ & 196.0 & 0.12 \\
\hline
\end{tabular}

Table 3 Intra- and interobserver biases before and 6 months after MitraClip implantation.

Tab. 3 Intra- und Interuntersucherabweichungen vor und 6 Monate nach MitraClip-Implantation.

Abbreviations: INTER = interobserver, INTRA = intraobserver, LAV = left atrial volume, LVEDV = left ventricular end-diastolic volume, LVESV = left ventricular end-systolic volume, RVEDV = right ventricular end-diastolic volume, RVESV = right ventricular end-systolic volume, $\mathrm{SD}=$ standard deviation

Abkürzungen: INTER = Interuntersucher, INTRA = Intrauntersucher, LAV = linksatriales Volumen, LVEDV = linksventrikuläres enddiastolisches Volumen, LVESV = linksventrikuläres endsystolisches Volumen, RVEDV = rechtsventrikuläres enddiastolisches Volumen, RVESV = rechtsventrikuläres endsystolisches Volumen, SD = Standardabweichung.

Table 4 CMR parameters at baseline and follow-up.

Tab. 4 MRT-Parameter vor (BL) und 6 Monate nach MitraClip-Implantation (FU).

\begin{tabular}{llll} 
Parameter & BL & FU & p-value \\
\hline LVEDVi $\left(\mathrm{ml} / \mathrm{m}^{2}\right)$ & $127(96-150)$ & $112(86-150)$ & 0.03 \\
\hline $\operatorname{LVESVi}\left(\mathrm{ml} / \mathrm{m}^{2}\right)$ & $82(54-91)$ & $69(48-99)$ & 0.03 \\
\hline LVSVi $\left(\mathrm{ml} / \mathrm{m}^{2}\right)$ & $44(38-54)$ & $42(36-53)$ & 0.19 \\
\hline $\operatorname{LVEF}(\%)$ & $35(31-44)$ & $39(31-45)$ & 0.37 \\
\hline $\operatorname{RVEDVi}\left(\mathrm{ml} / \mathrm{m}^{2}\right)$ & $94(75-103)$ & $99(77-123)$ & 0.91 \\
\hline $\operatorname{RVESVi}\left(\mathrm{ml} / \mathrm{m}^{2}\right)$ & $48(42-80)$ & $51(40-81)$ & 0.48 \\
\hline $\operatorname{RVSVi}\left(\mathrm{ml} / \mathrm{m}^{2}\right)$ & $36(28-48)$ & $42(30-52)$ & 0.25 \\
\hline $\operatorname{RVEF}(\%)$ & $40(28-54)$ & $45(34-51)$ & 0.58 \\
\hline $\operatorname{LAVi}\left(\mathrm{ml} / \mathrm{m}^{2}\right)$ & $87(55-124)$ & $92(48-137)$ & 0.20 \\
\hline
\end{tabular}

Abbreviations: $\mathrm{BL}=$ baseline, $\mathrm{FU}=$ follow-up, $\mathrm{IQR}=$ interquartile range, $\mathrm{LAV} \mathrm{A}=$ left atrial volume index, LVEDVi = left ventricular end-diastolic volume index, LVEF = left ventricular ejection fraction, LVESVi = left ventricular end-systolic volume index, LVSVi = left ventricular stroke volume index, RVEDVi = right ventricular end-diastolic volume index, RVEF = right ventricular ejection fraction, $R V S V i=$ right ventricular stroke volume index, RVESVi = right ventricular end-systolic volume index. Numbers are medians (interquartile range).

Abkürzungen: $\mathrm{BL}=$ Erstuntersuchung, $\mathrm{FU}=$ Follow-up, $\mathrm{IQR}=$ Interquartilsabstand, $\mathrm{LAVi}=$ linksatrialer Volumenindex, $\mathrm{LVEDVi}=$ linksventrikulärer enddiastolischer Volumenindex, LVEF = linksventrikuläre Ejektionsfraktion, LVESVi = linksventrikulärer endsystolischer Volumenindex, LVSVi = linksventrikulärer Schlagvolumenindex, $\mathrm{RVEDVi}=$ rechtsventrikulärer enddiastolischer Volumenindex, RVEF $=$ rechtsventriku läre Ejektionsfraktion, RVSVi = rechtsventriukärer Schlagvolumenindex, RVESVi = rechtsventrikulärer endsystolischer Volumenindex. Median (Interquartilsabstand) für kontinuierliche Daten.

culties in defining RV contours at trabeculae as well as in defining $\mathrm{RV}$ endocardial boundaries in the most basal slice in the area of transition into the outflow tract and the right atrium [16]. The largest intra- and interobserver differences were found for LA volume measurements, confirming recent data of Hudsmith et al. [16] and others [22] on the significant observer variability of LA volume measurements due to the inherent limitations of geometrical assumptions for estimating LA volume.

\section{Reverse LV remodeling}

The significant reduction of MR detected by echocardiography as well as of LV volumes detected by CMR underscores previous findings after percutaneous mitral valve repair. Recently, echocardiography has demonstrated a significant reduction in enddiastolic and end-systolic LV volumes 12 months after MC im- plantation in 2 larger cohorts of 144 and 63 patients, respectively $[5,6]$. In comparison to our CMR results, echocardiography failed to demonstrate a significant reduction of LV volumes in our study population. This discrepancy can be explained by the known limitations of echocardiography as a less precise tool in LV volume analysis $[23,24]$. Larger study populations are required to detect significant differences in cardiac volumes by echocardiography as compared to CMR. The proof of LV remodeling after MC implantation is important in the subgroup of patients with MR and severely reduced LV function: Chronic volume overload in MR is related to remodeling of the extracellular matrix with dissolution of collagen tissue and consecutive rearrangement and slippage of myocardial fibers $[25,26]$. Subsequent decompensation is characterized by progressive LV dilation, elevated diastolic LV pressure, increased systolic wall stress and reduced LV ejection fraction [27]. The poor outcome of mitral valve surgery in patients with severely reduced LV function could be potentially related to irreversible changes in the extracellular matrix as well as a result of the underlying disease such as dilative cardiomyopathy or MR itself [2]. Our CMR data on patients with a median LVEF of $35 \%$ underscore recent echocardiographic data on the potential for reverse $\mathrm{LV}$ remodeling after mitral valve repair in patients with MR and reduced LV function $[5,6]$.

\section{$\mathrm{RV}$ and LA remodeling}

The use of CMR to assess RV and LA volumes and function following $\mathrm{MC}$ implantation is attractive since echocardiographic assessment of these chambers is challenging [28]. However, we did not observe significant changes in end-diastolic or end-systolic RV volumes from baseline to follow-up. This finding may be related to preserved RV function and normal RV volumes at BL in our study population. RV volumes in our study were similar to normal values from healthy subjects in the literature [16]. Thus, no further reduction in RV volumes could be expected. In contrast, one would expect reverse LA remodeling after successful reduction of MR by MC implantation. LA volume and function were recently identified as important prognostic parameters [29]. Compared to the healthy cohort of Hudsmith et al. [16], our patients had severely enlarged left atrial volumes at BL. However, we did not find a reduction in LA volume from BL to FU. This could hypothetically either be related to the 6-month follow-up interval or to possibly irreversible LA structural changes in terms of myocardial fibrosis. Several recent studies observed profound structural 


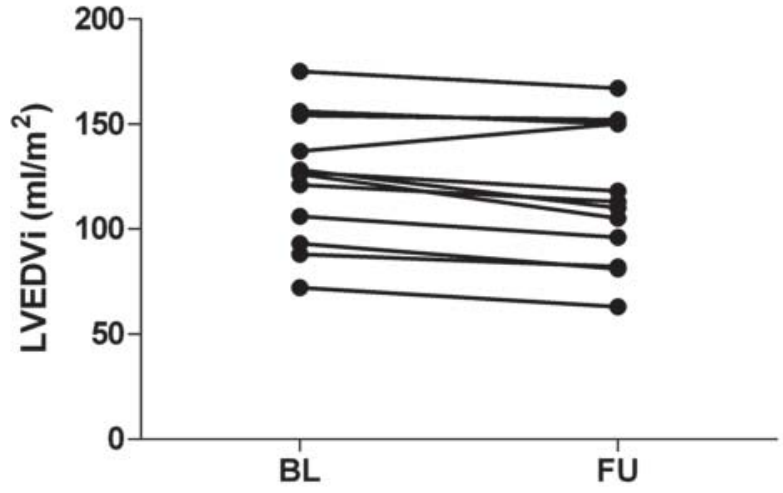

Fig. 4 LV volume indices. At 6-month follow-up a significant reduction was found for LVEDVi (median 127 [IQR 96 - 150] vs. 112 [86 - 150] ml/m²; $\mathrm{p}=0.03)$ and LVESVi $\left(82[54-91]\right.$ vs. $\left.69[48-99] \mathrm{ml} / \mathrm{m}^{2} ; \mathrm{p}=0.03\right)$. Abbreviations: LVEDVi = left ventricular end-diastolic volume index, LVES$\mathrm{Vi}=$ left ventricular end-systolic volume index.

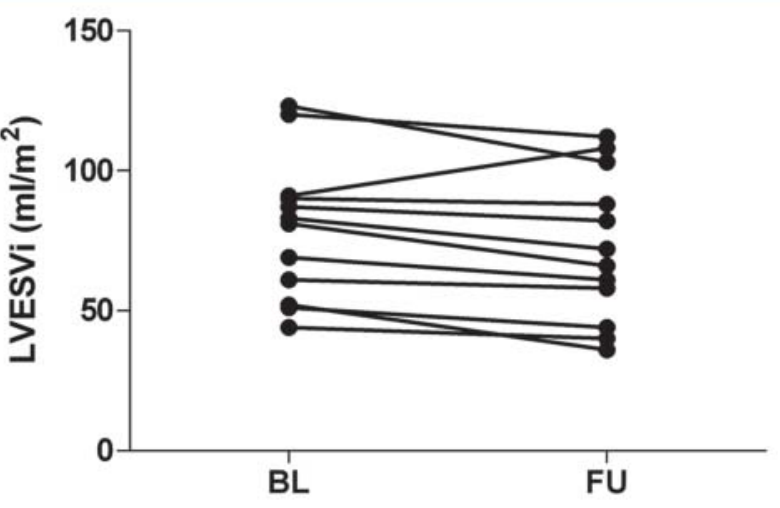

Abb.4 Indices der LV Volumina. Signifikante Reduktion von LVEDVi (median 127 [IQR $96-150$ ] vs. 112 [ $\left.86-150] \mathrm{ml} / \mathrm{m}^{2} ; \mathrm{p}=0,03\right)$ und LVESVi $(82$ [54 - 91] vs. 69 [48 - 99] $\left.\mathrm{ml} / \mathrm{m}^{2} ; p=0,03\right)$ nach einem Zeitraum von sechs Monaten. Abkürzungen: LVEDVi = Linksventrikulärer enddiastolischer Volumenindex, LVESVi = Linksventrikulärer endsystolischer Volumenindex.

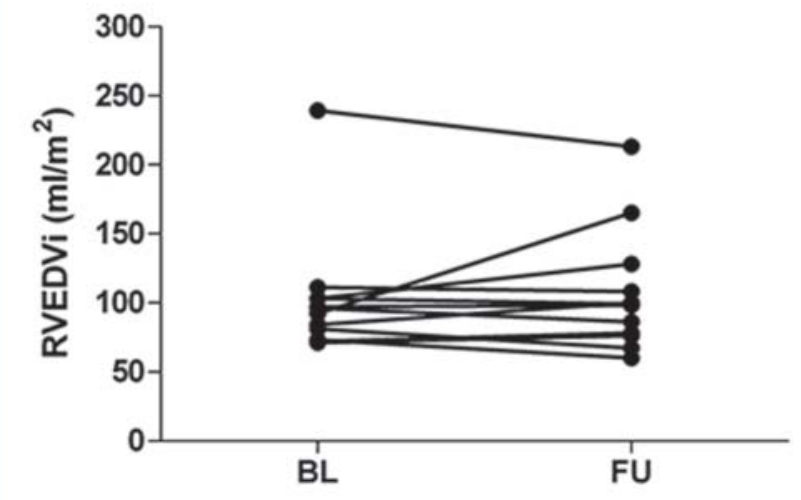

Fig. 5 RV volume indices. The differences in RVEDVi (median 94 [IQR 75 103] vs. 99 [77-123] $\left.\mathrm{ml} / \mathrm{m}^{2}\right)$ and RVESVi (48 [42 - 80] vs. 51 [40 - 81] $\mathrm{ml} /$ $\left.\mathrm{m}^{2}\right)$ were not statistically significant $(p=0.91$ and $p=0.48$, respectively) after six months. Abbreviations: RVEDVi = right ventricular end-diastolic volume index, RVESVi = right ventricular end-systolic volume index .

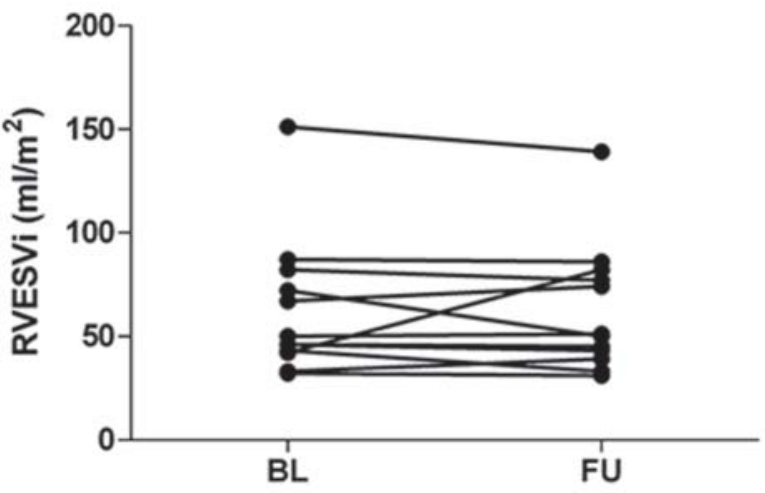

Abb.5 Indices der RV Volumina. Es zeigen sich keine signifikanten Unterschiede von RVEDVi (median 94 [IQR 75 - 103] vs. $99[77-123] \mathrm{ml} / \mathrm{m}^{2}$ ) und RVESVi $\left(48[42-80]\right.$ vs. $\left.51[40-81] \mathrm{ml} / \mathrm{m}^{2}\right)(p=0,91$ bzw. $p=0,48)$ Abkürzungen: RVEDVi = rechtsventrikulärer enddiastolischer Volumenindex, $\mathrm{RVESVi}=$ rechtsventrikulärer endsystolischer Volumenindex changes of the LA in patients with chronic MR [30 - 32]. LA enlargement is accompanied by chronic inflammatory changes, cellular hypertrophy and interstitial fibrosis [33]. Thus, interstitial fibrosis in patients with chronic mitral regurgitation may result in irreversible LA dilatation. The assessment of LA fibrosis by delayed enhancement CMR could be used to evaluate this aspect and identify patients with a low likelihood of reverse LA remodeling [34]. Furthermore, 6 patients in our cohort had chronic atrial fibrillation. These patients were unlikely to experience reverse LA remodeling due to the profibrotic effect of the arrhythmia itself [35].

\section{Limitations}

This pilot study is mainly limited by its small study cohort. Of note, due to multiple testing in our small study cohort, the statistically significant results should not be interpreted as given facts and require focused testing in a larger study cohort. In addition, the observed reduction of LV volumes in our study population can be a result of regression to mean effect. Nevertheless, all patients in our study population had a reduction in LVESVi and $92 \%$ had a reduction of LVEDVi from BL to FU. We are therefore confident that there was reverse LV remodeling in our study population in agreement with recent data of larger studies such as by Rudolph et al. [6]. An additional aspect could be the use of retrospective gating in our study population, including $50 \%$ patients with atrial fibrillation. However, image quality was sufficient in these patients, so that prospective triggering was deemed unnecessary.

\section{Conclusion}

$\nabla$

CMR allows reproducible assessment of cardiac volumes in patients with implanted MC devices. Furthermore, CMR findings indicate that MC implantation results in reverse LV but not in RV or LA remodeling. 


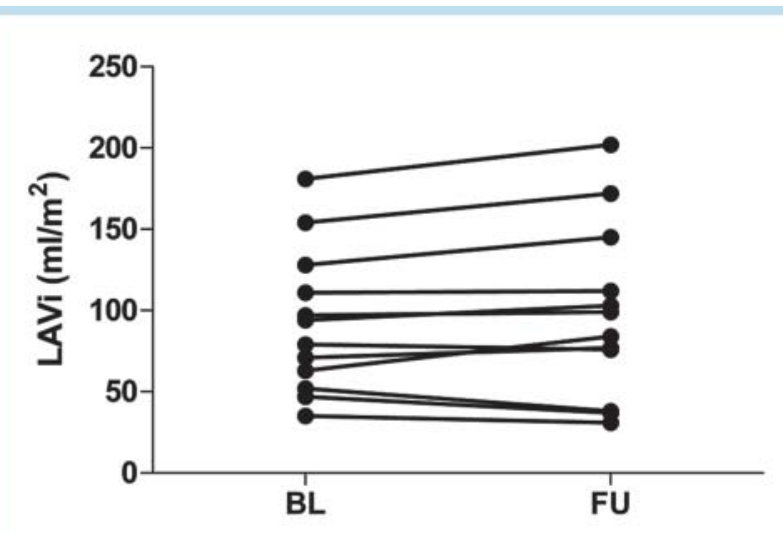

Fig. 6 LA volume index. Non-significant change in $L A V i$ from $B L$ to FU (median 87 [IQR 55-124] vs. $92[48-137] \mathrm{ml} / \mathrm{m}^{2}, \mathrm{p}=0.20$ ). Abbreviations: $\mathrm{LAVi}=$ left atrial volume index.

Abb. 6 Linksatrialer Volumenindex. Keine signifikante Änderung des LAVi 6 Monate nach MitraClip-Implantation (median 87 [IQR 55 - 124] vs. $92[48-137] \mathrm{ml} / \mathrm{m}^{2}, \mathrm{p}=0,20$ ). Abkürzungen: $\mathrm{LAVi}=$ linksatrialer Volumenindex.

\section{Clinical relevance of the study}

- Volumetric analysis via CMR after percutaneous mitral valve repair is feasible despite artifacts.

- Our results of cardiac volumetric analysis indicate that after a period of 6 months percutaneous mitral valve repair results in significant reduction of left ventricular volumes in terms of favorable reverse remodeling but not in significant changes of right ventricular or left ventricular volumes.

\author{
Affiliations \\ 1 Cardiology, University Heart Center, Hamburg \\ 2 Cardiology, Rigshospitalet, Copenhagen \\ 3 Cardiology, Klinikum Dortmund \\ ${ }^{4}$ Radiology, University Medical Center Hamburg-Eppendorf, Hamburg \\ ${ }^{5}$ Cardiovascular Surgery, University Heart Center, Hamburg
}

\section{References}

1 Trichon BH, Felker GM, Shaw LK et al. Relation of frequency and severity of mitral regurgitation to survival among patients with left ventricular systolic dysfunction and heart failure. Am J Cardiol 2003; 91: 538-543

2 Bonow RO, Masoudi FA, Rumsfeld JS et al. ACC/AHA classification of care metrics: performance measures and quality metrics: a report of the American College of Cardiology/American Heart Association Task Force on Performance Measures. Circulation 2008; 118: 2662-2666

3 Alfieri O, Maisano F, De Bonis $M$ et al. The double-orifice technique in mitral valve repair: a simple solution for complex problems. J Thorac Cardiovasc Surg 2001; 122: 674-681

4 Feldman T, Wasserman HS, Herrmann HC et al. Percutaneous mitral valve repair using the edge-to-edge technique: six-month results of the EVEREST Phase I Clinical Trial. J Am Coll Cardiol 2005; 46: 2134 2140

5 Feldman T, Foster E, Glower DD et al. Percutaneous repair or surgery for mitral regurgitation. N Engl J Med 2011; 364: 1395-1406

6 Rudolph V, Knap M, Franzen $O$ et al. Echocardiographic and clinical outcomes of MitraClip therapy in patients not amenable to surgery. J Am Coll Cardiol 2011; 58: 2190-2195

7 Achenbach S, Barkhausen J, Beer $M$ et al. Konsensusempfehlungen der DRG/DGK/DPGK zum Einsatz der Herzbildgebung mit Computertomographie und Magnetresonanztomographie. Rofo 2012; 184: 345 - 368
8 Hundley WG, Bluemke DA, Finn JP et al. ACCF/ACR/AHA/NASCI/SCMR 2010 expert consensus document on cardiovascular magnetic resonance: a report of the American College of Cardiology Foundation Task Force on Expert Consensus Documents. Circulation 2010; 121: $2462-2508$

9 Zoghbi WA, Enriquez-Sarano M, Foster E et al. Recommendations for evaluation of the severity of native valvular regurgitation with two-dimensional and Doppler echocardiography. J Am Soc Echocardiogr 2003; 16: 777-802

10 Foster E, Wasserman HS, Gray W et al. Quantitative assessment of severity of mitral regurgitation by serial echocardiography in a multicenter clinical trial of percutaneous mitral valve repair. Am J Cardiol 2007; 100: 1577-1583

11 Kramer CM, Barkhausen J, Flamm SD et al. Standardized cardiovascular magnetic resonance imaging (CMR) protocols, society for cardiovascular magnetic resonance: board of trustees task force on standardized protocols. J Cardiovasc Magn Reson 2008; 10: 35

12 Heiberg E, Sjogren J, Ugander M et al. Design and validation of Segment-freely available software for cardiovascular image analysis. BMC Med Imaging 2010; 10: 1

13 Lang RM, Bierig M, Devereux RB et al. Recommendations for chamber quantification. Eur J Echocardiogr 2006; 7: 79-108

14 Dubois $D$, Dubois EF. A formula to estimate the approximate surface area if height and weight are known. Arch Intern Med 1916; 17: $863-871$

15 Altiok E, Paetsch I, Jahnke C et al. Percutaneous edge-to-edge mitral valve repair: assessment of immediate post-procedural treatment effect using color 3-dimensional transesophageal echocardiography and cardiac magnetic resonance imaging. J Am Coll Cardiol 2011; 58: e21

16 Hudsmith LE, Petersen SE, Francis JM et al. Normal human left and right ventricular and left atrial dimensions using steady state free precession magnetic resonance imaging. J Cardiovasc Magn Reson 2005; 7: 775-782

17 Luijnenburg SE, Robbers-Visser D, Moelker A et al. Intra-observer and interobserver variability of biventricular function, volumes and mass in patients with congenital heart disease measured by CMR imaging. Int J Cardiovasc Imaging 2009; 26: 57-64

18 Mooij CF, de Wit CJ, Graham DA et al. Reproducibility of MRI measurements of right ventricular size and function in patients with normal and dilated ventricles. J Magn Reson Imaging 2008; 28: 67-73

19 Robbers-Visser D, Boersma E, Helbing WA. Normal biventricular function, volumes, and mass in children aged 8 to 17 years. J Magn Reson Imaging 2009; 29: $552-559$

20 Maceira AM, Prasad SK, Khan M et al. Reference right ventricular systolic and diastolic function normalized to age, gender and body surface area from steady-state free precession cardiovascular magnetic resonance. Eur Heart J 2006; 27: 2879-2888

21 Winter MM, Bernink FJ, Groenink $M$ et al. Evaluating the systemic right ventricle by CMR: the importance of consistent and reproducible delineation of the cavity. J Cardiovasc Magn Reson 2008; 10: 40

22 Sievers B, Kirchberg S, Addo $M$ et al. Assessment of left atrial volumes in sinus rhythm and atrial fibrillation using the biplane area-length method and cardiovascular magnetic resonance imaging with TrueFISP. J Cardiovasc Magn Reson 2004; 6: 855 - 863

23 Grothues F, Welte T, Grote HJ et al. Floating aortic thrombus in systemic aspergillosis and detection by transesophageal echocardiography. Crit Care Med 2002; 30: 2355-2358

24 Jenkins C, Bricknell K, Chan J et al. Comparison of two- and three-dimensional echocardiography with sequential magnetic resonance imaging for evaluating left ventricular volume and ejection fraction over time in patients with healed myocardial infarction. Am J Cardiol 2007; 99: 300-306

25 Perry GJ, Wei CC, Hankes GH et al. Angiotensin II receptor blockade does not improve left ventricular function and remodeling in subacute mitral regurgitation in the dog. J Am Coll Cardiol 2002; 39: 13741379

26 Ross J Jr. Afterload mismatch in aortic and mitral valve disease: implications for surgical therapy. J Am Coll Cardiol 1985; 5: 811-826

27 Gaasch WH, Meyer TE. Left ventricular response to mitral regurgitation: implications for management. Circulation 2008; 118: 2298-303

28 Jurcut R, Giusca S, La Gerche A et al. The echocardiographic assessment of the right ventricle: what to do in 2010? Eur J Echocardiogr 2010; 11: $81-96$ 
29 Tsang TS, Barnes ME, Gersh BJ et al. Left atrial volume as a morphophysiologic expression of left ventricular diastolic dysfunction and relation to cardiovascular risk burden. Am J Cardiol 2002; 90: 1284-1289

30 Anne $W$, Willems $R$, Roskams $T$ et al. Matrix metalloproteinases and atrial remodeling in patients with mitral valve disease and atrial fibrillation. Cardiovasc Res 2005; 67: 655-666

31 Kuppahally SS, Akoum N, Burgon NS et al. Left atrial strain and strain rate in patients with paroxysmal and persistent atrial fibrillation: relationship to left atrial structural remodeling detected by delayed-enhancement MRI. Circ Cardiovasc Imaging 2010; 3: 231 - 239

32 Verheule S, Wilson E, Everett T et al. Alterations in atrial electrophysiology and tissue structure in a canine model of chronic atrial dilatation due to mitral regurgitation. Circulation 2003; 107: 2615-2622
33 Borg AN, Pearce KA, Williams SG et al. Left atrial function and deformation in chronic primary mitral regurgitation. Eur J Echocardiogr 2009; 10: $833-840$

34 Oakes RS, Badger TJ, Kholmovski EG et al. Detection and quantification of left atrial structural remodeling with delayed-enhancement magnetic resonance imaging in patients with atrial fibrillation. Circulation 2009; 119: $1758-1767$

35 Wijffels MC, Kirchhof CJ, Dorland R et al. Atrial fibrillation begets atrial fibrillation. A study in awake chronically instrumented goats. Circulation 1995; 92: 1954-1968 